\title{
Description of Transmigrants' Socio-Cultural Environment in the Regencies of Banyuasin and Ogan Ilir, South Sumatra Province, Indonesia
}

\author{
Malta \\ Faculty of Math and Science \\ Open University \\ Indonesia \\ Sumardjo \\ Faculty of Human Ecology \\ Bogor Agriculture University \\ Indonesia \\ Anna Fatchiya \\ Faculty of Human Ecology \\ Bogor Agriculture University \\ Indonesia \\ Djoko Susanto \\ Faculty of Human Ecology \\ Bogor Agriculture University \\ Indonesia
}

\begin{abstract}
Transmigration is an important alternative in overcoming various problems in the field of population. A ttransmigrations program not only equalizes populationdistributionbutitalsospreads productive human resources to explore every possiblepotential tobeableto improve the welfare of thepeoplein the transmigration site and in itssurrounding areas. The socio-cultural aspect becomes the context that colors the direction of transmigration development. This research aimed to analyze the socio-cultural conditions of transmigrates in farming. The study was conducted from May 2016 to January 2017. The total population was 3,537 transmigrant households. The number of the samples in this study was determined using Slov in formula. The study involved 359 respondents determined by stratified random sampling. The rresearch data consisted of primary data and secondary data. The primary data was obtained through structured interviews, in-depth interviews, and field observations. The results of the study showed that the socio-cultural conditions of transmigrants in theregencies of Banyuasin and OganIlirin South Sumatra Province were in thelowcategoryin termsofthesupportof community leadersand group existence. However, it is high in the harmony of social relations.
\end{abstract}

Keywords: socio-cultural, transmigrant, transmigration

\section{Introduction}

Indonesia is the largest archipelagic country in the world, and it is quite understandable if the country has a very unequal population distribution. Based on data from the Central Bureau of Statistics (BPS) in 2013, around $57.49 \%$ of the total Indonesian population lived on the islands of Java and Madura, covering only $6.96 \%$ of the Indonesia's land area. Meanwhile, Kalimantan, the largest island in Indonesia (27.22\% of the Indonesia's land area), was only inhabited by around $5.8 \%$ of the Indonesia's totalpopulation. Similarly, Papua, which covers $22.83 \%$ of the Indonesia's land area, was inhabited by less than two percent of the Indonesia's total population.

It is true that population is the initial capital of development and a potential economic driver; however, the population concentration in an area, such as on Java Island, undoubtedly triggers various problems. A study conducted by Malamassam and Surtiari (2011) states that high population density in an area results in greater utilization of natural resources and the excessive use can lead to a decrease in environmental quality. 
Noveria (2011) states that a large population creates demands for various social and economic services in such areas as education, health, markets, and employment opportunities. Limited carrying capacity will be a threat to the fulfillment of socio-economic rights. Inadequate employment opportunities will create unemployment that will worsen people's economic conditions which in turn can have a negative impact on the social environment. BPS data (2017) proved that the problem of inequality in population distribution was followed by other problems such as unemployment. The number of the unemployed people in Indonesia in 2017 reached 7.01 million people or $5.33 \%$ of the total workforce in Indonesia, and $60.2 \%$ (4.2 million people) of the total unemployment was found in Java.

Transmigration is an important alternative in overcoming various problems in the field of population. A transmigration program not only equalizes populationdistributionbutitalsospreads productive human resources to explore every possiblepotential tobeableto improve the welfare of thepeoplein the transmigration site and in itssurrounding areas. Romdiati and Noveria (2002) state that for regions that are still sparsely populated, inward migration can have a positive impact on the economy and development. The entry of the working age population will increase the number of workers who can utilize the natural potential of the area. The migrants can also play a role in progressing the economy, among others, through their involvement in the trade sector.

Law number 29 of 2009 concerning Transmigration states that the development of transmigration is an effort to accelerate the development of small towns, especially outside Java by enhancing their role as a driving force for regional development to improve regional competitiveness which is still low as a result of the wide gaps between regions. The gaps mentioned are particularly between rural and urban areas, Java and outside Java, east and west regions, including the low linkages between the growth centers and the hinterland regions, and between villages and cities.

Along with the era of regional autonomy, the implementation of the transmigration program has also entered a new era with a new paradigm. Transmigration is no longer merely a resettlement program, but it is also man effort to develop the region and establish growth centers, as well as to fulfill the human resource needs required to develop the potential of available resources (Manuwiyoto, 2004; Saksono, 2011). The target of the implementation of transmigration development is to improve the ability and productivity of transmigration communities, build their independence and realize an integration in transmigration settlements so that the economic, social and cultural aspects are able to grow and develop sustainably. The objectives of the transmigration program as mentioned above are the ideal targets that are expected to be realized, but the conditions of the transmigrants in the transmigration areas must be a major concern in order to realize these goals. The fact is that the transmigrants in the transmigration areas are generally from lower-class people who have low education and are economically disadvantaged (Manuwiyoto, 2004; Saleh, 2005; Kemenakertrans, 2013). Transmigrants are migrants from various regions with different social and cultural backgrounds. They must start and live a new life in an entirely new area. The situation is very different from the conditions of their previous region, including the natural conditions and the new social, economic and cultural environments. They have to face these challenges to increase living demands and to survive in an increasingly competitive business competition. Although there is life insurance assistance and production facilities at the beginning of placement, it is not always easy to run and develop business activities.

Given the above conditions, it is necessary to develop community and transmigration areas that are designed in the framework of making transmigration communities capable of carrying out their business activities, so that welfare can be achieved. The transmigration community assistance program is an activity carried out after placement with the aim of strengthening the economic, social and cultural life of transmigrants in the settlements that have been built.

The transmigration policy still directs transmigrants to work in the agricultural sector with land-based production businesses, and there have not been many attempts to diversify the pattern of transmigrant businesses. Transmigration business and settlement patterns are almost entirely built with agricultural development orientation (Manuwiyoto, 2008; Kemenakertrans, 2013). The implication of this policy is that the transmigrants are generally farmers or families / communities who are ready to run businesses in the agricultural sector. Community development and transmigration areas in general mean the development of farmer communities in farming in transmigration areas. Transmigrants as business actors are individuals who are strongly influenced by the forces around them in carrying out business activities. 
Inter-ethnic kinship levels, socio-cultural contacts, and inter-cultural intermingling (including intermingling with indigenous people) in transmigration areas greatly determine the continuity and smooth operation of transmigrant businesses. Tulak et al., (2009) mention that the socio-cultural aspect should be the context in which the transmigration area will be able to develop. The socio-cultural environment conditions are very important to study since they can then be used as a basis for The development of community and transmigration areas. The aim of this study was to analyze the social and cultural conditions of transmigrants in farming.

\section{Research methods}

The type of research used belongs to descriptive research which explains such research subjects as group profiles, processes, mechanisms or relationships, giving verbal and numerical descriptions, tracing information to explain findings, or various things that are contrary to beliefs (Neuman, 1994). The study was conducted from May 2016 to January 2017. The location of the study was in the Regencies of Banyuasin and Ogan Ilir, South Sumatra Province, with consideration being areas with a large number of transmigrants in South Sumatra Province. The population included 3,537 transmigrant households. The sample size in this study was determined using the Slovin formula. The number of samples was 359 respondents. The sampling method was stratified random sampling. The data collection was conducted to get primary data and secondary data. The primary data ware obtained through structured interviews, in-depth interviews, and field observations.

\section{ResultsandDiscussion}

The research results for the aspects of socio-cultural environment in the two regencies showed that thesupport of community leaders was low, the group existence was low, and the harmony of social relations was high (Table 1). This condition also described the socio-cultural life of the transmigration sites. The conditions arefurther explained in the following description.

\subsection{CommunityLeaderSupport}

The support of community leaders in transmigrant farming activities was in the low category (Table 1). The low level of the support could be seen from the fact that the community leaders did not providemuch information related to farming activities. In addition, they were not very helpful when the transmigrants faced problems in running their farm. Furthermore, the community leaders seldom, if any, try to motivate the transmigrants to seek and disseminate new ideas or technologies for business progress. This is because the community leaders in the transmigration area also had limited accesstoinformationontechnologyandinnovation.

Table 1 Distribution of respondents based on social and cultural environment support in Banyuasin and Ogan Ilir in 2016

\begin{tabular}{|l|l|l|c|c|}
\hline $\begin{array}{l}\text { Sub Variable of socio-cultural } \\
\text { environment support }\end{array}$ & Category & \multicolumn{2}{|l|}{ Regency } & $\begin{array}{l}\text { Total } \\
\text { (n=359) }\end{array}$ \\
\cline { 3 - 5 } & & $\begin{array}{l}\text { Banyuasin } \\
(\mathrm{n}=284)\end{array}$ & $\begin{array}{l}\text { Ogan Ilir } \\
(\mathrm{n}=75)\end{array}$ & \\
\cline { 3 - 5 } & & $\%$ & $\%$ & $\%$ \\
\hline \multirow{2}{*}{$\begin{array}{l}\text { Support of community leaders } \\
\text { Avarage score: } 38,5\end{array}$} & Low & 61.6 & 52.0 & 59.6 \\
\cline { 2 - 5 } & Medium & 16.2 & 30.7 & 19.2 \\
\cline { 2 - 5 } & High & 22.2 & 17.3 & 21.2 \\
\cline { 2 - 5 } & Total & 100.0 & 100.0 & 100.0 \\
\hline \multirow{2}{*}{$\begin{array}{l}\text { Group existence** } \\
\text { Average score: } 41,3\end{array}$} & Low & 58.8 & 25.3 & 51.8 \\
\cline { 2 - 5 } & Medium & 23.9 & 57.3 & 30.9 \\
\cline { 2 - 5 } & High & 17.3 & 17.4 & 17.3 \\
\cline { 2 - 5 } & Total & 100.0 & 100.0 & 100.0 \\
\hline \multirow{2}{*}{$\begin{array}{l}\text { Harmony of social relations } \\
\text { Average score: } 97,6\end{array}$} & Low & 0.0 & 0.0 & 0.0 \\
\cline { 2 - 5 } & Medium & 0.0 & 2.7 & 0.6 \\
\cline { 2 - 5 } & High & 100.0 & 97.3 & 99.4 \\
\cline { 2 - 5 } & Total & 100.0 & 100.0 & 100.0 \\
\hline
\end{tabular}

Note: $* *$ significantly different on $\alpha=0,01$

Average score: Low $=0-50$, Medium $=51-75$, High $=76-100$

When the category did not appear, the percentage of all columns was 0,0 
In general, the support of community leaders in the two regencies was low. However. when compared to other sources of support, the support from village / hamlet officials was higher than the support of other figures (Table 2). Village / hamlet officials are an extension of the regional government, so they are often involved in government activities related to the community development and agricultural development. This makes the village / hamlet apparatus interact more with the transmigrant community (compared to other sources of support) in the matter of farming development.

Table 2 Percentage of respondents based on perceptions about the support of community leaders in Banyuasin and Ogan Ilir in 2016

\begin{tabular}{|c|c|c|c|c|c|c|}
\hline \multirow{3}{*}{ Support of community leaders } & \multicolumn{2}{|c|}{$\begin{array}{l}\text { Banyuasin } \\
(\mathrm{n}=284)\end{array}$} & \multicolumn{2}{|c|}{ Ogan Ilir $(\mathrm{n}=75)$} & \multicolumn{2}{|c|}{ Total $(n=359)$} \\
\hline & $\begin{array}{l}\text { Less } \\
\text { suppor } \\
\text { tive }\end{array}$ & $\begin{array}{l}\text { suppo } \\
\text { rtive }\end{array}$ & $\begin{array}{l}\text { Less } \\
\text { suppo } \\
\text { rtive }\end{array}$ & $\begin{array}{l}\text { supporti } \\
\text { ve }\end{array}$ & $\begin{array}{l}\text { Less } \\
\text { suppo } \\
\text { rtive }\end{array}$ & $\begin{array}{l}\text { support } \\
\text { ive }\end{array}$ \\
\hline & $(\%)$ & $(\%)$ & $(\%)$ & $(\%)$ & $(\%)$ & $(\%)$ \\
\hline Support of village / hamlet apparatus & 77.8 & 22.2 & 82.7 & 17.3 & 78.8 & 21.2 \\
\hline Support of religious leaders & 90.1 & 9.9 & 81.3 & 18.7 & 88.3 & 11.7 \\
\hline $\begin{array}{l}\text { Support ofadat leaders / community } \\
\text { leaders }\end{array}$ & 87.3 & 12.7 & 76.0 & 24.0 & 85.0 & 15.0 \\
\hline Support ofyouth leaders & 100.0 & 0.0 & 100.0 & 0.0 & 100.0 & 0.0 \\
\hline
\end{tabular}

Since community leaders directly deal with the community, they have the potential to contribute to the development in the transmigration sites. Therefore, their role should be optimized in the development of transmigration communities. They can influence the attitudes and behavior of the communities through informal channels. Community leaders can be the driving force and dynamics of development. According to Slamet (2003), community leaders can carry out such important roles as: (1) information providers, (2) motivators, (3) facilitators of diffusion process, (4) connectors between systems, and (5) community drivers and guides towards development.

\subsection{Group Existence}

The existence of the farmer groups which are expected to be able to help transmigrants carry out their farming activities was in the low category (Table 1). Group programs have not been fully in line with the needs of transmigrates in carrying out their farming activities, thus not fully assisting the transmigrants with their problems with farming activities. In terms of access to information about crop cultivation and in obtaining production inputs, the existence of farmer groups is quite helpful to transmigrants but not in terms of access to capital and markets (Table 3). The results of this study are in line with the findings of Amanah and Farmayanti (2016), saying that group institutions on farmers still have limitations in accessing and utilizing information for business development.

Table 3 Percentage of respondents based on perceptions of the benefits of grouping in Banyuasin and Ogan Ilir in 2016

\begin{tabular}{lcccccc}
\hline Benefits of grouping & \multicolumn{2}{c}{ Banyuasin $(\mathrm{n}=284)$} & \multicolumn{2}{c}{ Ogan Ilir $(\mathrm{n}=75)$} & \multicolumn{2}{c}{ Total $(\mathrm{n}=359)$} \\
\cline { 2 - 7 } & No & Yes & No & Yes & No & Yes \\
\cline { 2 - 7 } & $(\%)$ & $(\%)$ & $(\%)$ & $(\%)$ & $(\%)$ & $(\%)$ \\
\hline $\begin{array}{l}\text { Obtaining information on } \\
\text { cultivation }\end{array}$ & 29.2 & 70.8 & 24.3 & 75.7 & 28.5 & 71.5 \\
Access to capital/loan & & & & & & \\
Access to production input & 85.7 & 14.3 & 87.4 & 12.6 & 86.1 & 13.9 \\
Facilitating marketing & 47.7 & 52.3 & 39.1 & 60.9 & 45.9 & 54.1 \\
\hline
\end{tabular}

There are significant differences between the existence of farmer groups in Banyausin regency and Ogan Ilir Regency. The farmer groups in Ogan Ilir were more active (60 percent) than those in Banyuasin (33 percent). 
The activeness of the transmigrant assistants from the Integrated City Independent Management Unit (KTM) in empowering groups has a positive effect on the activeness of the groups in the KTM area. Seventy-five percent of the locations of Transmigration Settlements (TS) in Ogan Ilir Regency are KTM regions.

In the early days of transmigrant placement, the formation of farmer groups was initiated by a companion officer from the Transmigration Department. Later on, the development of group activities was accompanied by an extension agent from the Department of Agriculture, and in the KTM area it was also accompanied by a companion from the KTM management.

The results of the interviews with transmigrants showed that there were several reasons why many transmigrants were not actively involved in farmer groups. First, the existing groups were not suitable for their needs, for example,the group activities like frequant gatherings when there were visitorstook much time. Second, the group activities did not show any positive changes or development. Third, the transmigrants had less pleasant experience with their previous group activities. Fourth, the activities of farmer groups did not solve the problems of transmigrants. Fifth, many transmigrants did not know the benefits of the group. Transmigrant good knowledge of the benefits of farmer groups determines transmigrant involvement in farmer groups and group development.

In active groups, the average group meeting was done once a month. Activities organized by farmer groups included discussing group agendas, arisan and religious studies. The matters discussed in group meetings included sharing information about cultivation techniques, arranging rotation for mutual cooperation, overcoming pest, finance, and saprodi recommendations. Through the media of farmer groups, extension agents held agricultural business counseling.The biggest benefit of farmer groups for transmigrants is access to information about crop cultivation (Table 3). Sources of information in groups come from group leaders, fellow members, as well as from extension workers who come to the group. Additionally, the group members also enjoy the ease of obtaining production input, subsidized fertilizer distributed through groups, and buying plant medicines at kiosks belonging to groups that are available at any time. Transmigrants do not need to pay transportation costs to buy production facilities to the city or regency center. All of these can make farming activities very efficient.

The benefits of joining the group become the factors that motivate transmigrants to become group members. This motivation is related to the needs that can be met if they are group members. A motivational theory such as McClelland's theory of need (Barbutto et al., 2004) suggests that there is a very strong link between motivation and need, namely the motivation of a person to be awakened from the need he feels. Transmigrants as new residents at transmigration sites and as social communities basically have a group awareness. The awareness of grouping is a natural condition that is owned by each human being to be able to survive in his social life. A farmer group is an institution that can become a forum for transmigrants in building cohesiveness and mutual progress. Slamet (2003) suggests that a farmer group is an effective communication forum at the farm level. A group becomes a learning forum which is a process of empowerment; continuously grow in gand developing the independence of farmers.

\subsection{HarmonyofSocialRelations}

The harmony of social relations of the people in the transmigration area was in the high category (Table 1). This was evidenced by the never-occurring disputes at the Transmigration Settlement locations, both among fellow transmigrants and between transmigrants and local residents (Table 4). The harmony of the relationship was also indicated by the frequent marriages between indigenous people and transmigrants from Java. Transmigrant communities consider that mixed marriages between transmigrants and indigenous people were commonplace. The harmony of relations in the community at the transmigration site also supports the smooth process of information sharing and innovation in the community.

Table 4 Percentage of respondents based on the level of community relationship harmony in Banyuasin and Ogan Ilir in 2016

\begin{tabular}{lllllll}
\hline & \multicolumn{2}{l}{$\begin{array}{l}\text { Banyuasin } \\
(\mathrm{n}=284)\end{array}$} & & \multicolumn{2}{l}{ Ogan Ilir (n=75) } & \multicolumn{2}{l}{ Total (n=359) } \\
\cline { 2 - 8 } Indicator & never & often & never & often & never & often \\
\cline { 2 - 8 } & $(\%)$ & $(\%)$ & $(\%)$ & $(\%)$ & $(\%)$ & $(\%)$ \\
\hline $\begin{array}{l}\text { Conflicts among new transmigrants } \\
\begin{array}{l}\text { Conflicts between transmigrants } \\
\text { local people }\end{array}\end{array}$ & 100.0 & 0.0 & 100.0 & 0.0 & 100.0 & 0.0 \\
\hline
\end{tabular}


Openness to culture, both the culture of newcomers and the culture of local communities, occurred in both regencies. National and religious celebrations such as Independence Day on August 17 and Eid al-Fitr are often enlivened by displaying performances from two different customs. Cultural art has been considered by the local community as a wealth that must be enjoyed together. When the transmigration community of Javanese origin displayed a performing art, for example, kuda lumping, the indigenous community would watch. Similarly, if there are indigenous people who hold local cultural art performances, transmigrant communities also come to enjoy them. They consider all performances from different tribes as theirs to be preserved. This guarantees the continuity of newcomer customs and local customs. These conditions diminish the causes of conflict between trasmigrants and indigenous people.

Among the younger generation, joint activities are also often conducted, especially in the field of sports. Transmigrants hold sporting events, regardless of differences in ethnicity, religion and race. Through these activities, they strengthened their relationship with the communication, thus strengthening the integration of transmigrants with indigenous people. There was no difference in association between residents who joined transmigration and indigenous people. There was also no activity in schools causing a chaos between transmigrant children and the children of indigenous people. The results of this study was in contrast with the findings of Febryansah (2015) which stated that the transmigration program was often considered by the local people as jawanisasi which shifts native local culture, and this might trigger conflicts because of the local residents' concerns about the sustainability of their customs and culture.

Government policy in the research area on giving indigenous people the opportunity to follow transmigration with a portion of 50 percent of all the transmigrant participants in each PT had decreased the level of social jealousy of the indigenous people. Local people feel that the transmigration program in their area also benefits the surrounding population, especially by being included as transmigrants receiving the same facilities.

The adaptation process of transmigrants with local transmigrants is an important factor for the creation of good interaction in the transmigration area. In order to accelerate the intermingling between local transmigrants and non-local transmigrants, the locations of houses were arranged alternately, for example, the first house for a local transmigrant, then the second house for a non-local transmigrant, and the third house for a local transmigrant, and so on. This avoids grouping of associations only among fellow non-local transmigrants or just fellow indigenous people, resulting in social interaction. The interaction creates a sense of mutual need for each other so that communication and friendship are naturally established.

Social interaction is a dynamic social relationship which involves relationships between individuals, group and group, as well as between individual and group that influence each other. Humans will not be able to live harmoniously in their environment if they do not have good social relations with one another. The factor of social interaction is very decisive for the sake of the success of social relations in a society. Soekanto (1996) states that social interaction is the key to all social life and without it there will not be a common life.

\section{Conclusion}

The socio-cultural conditions of the transmigrants in the regencies of Banyuasin and Ogan Ilir in South Sumatra Province werein thelow category in terms of the support of community leaders and group existencebut in the high category as far as the harmony of social relations is concerned.

\section{Acknowledgements}

ThankstotheDirectorateof Resources forScience, Technology andHigherEducation, MinistryofResearch, Technology andHigherEducationofthe Republic of Indonesia, as a sourceoffundingforthisresearch.

\section{References}

Amanah, S., \&Farmayanti, N. (2014). Pemberdayaansosialpetani-nelayan, keunikanagroekosistem, dan dayasaing. Jakarta: Yayasan PustakaObor Indonesia.

Badan Pusat Statistik. (2013). Data Kependudukan. Jakarta: BPS.

Badan Pusat Statistik. (2017). Data Kependudukan. Jakarta: BPS.

Barbutto, J.E., Trout, S.K., \&Brown, L.L. (2004). Identifying sources motivation of adult rural workers. Journal of Agricultural Education. 45:3. 
Febryansah. (2015). Tingkat dayaterimamasyarakatlokalterhadaptransmigran. Yogyakarta: Universitas Gadjah Mada.

Kementerian Tenaga Kerja dan Transmigrasi. (2013). Naskahakademikarah dan kebijakanKetransmigrasianTahun 2015-2019. Jakarta: Kemenakertrans RI.

Malamassam, M.A., \&Surtiari, G.A.K. (2011). Identifikasikesesuaianpenduduk dan lingkungan di PulauJawa. Di dalam: Suhendra, F, \&Hartiningsih, R.W (Eds),Pertumbuhanpenduduk dan kesejahteraan(pp. 205231).Jakarta: LIPI Press

Manuwiyoto, M. (2004). Mengenal dan memahamitransmigrasi. Jakarta: PustakaSinarHarapan.

Manuwiyoto, M. (2008). Transformasiparadigmabarupembangunantransmigrasi. Jakarta: Pusat Penelitian dan PengembanganTransmigrasiDepartemen Tenaga Kerja dan Transmigrasi.

Neuman, L. (1994). Social research methods: qualitative and quantitativeapproaches. Boston: Allyn and Bacon.

Noveria, M. (2011). Pertumbuhanpenduduk dan dampaknyaterhadapkesejahteraan. Di dalam: Suhendra, F, \&Hartiningsih, R.W (Eds). Pertumbuhanpenduduk dan kesejahteraan(pp.1-22).Jakarta: LIPI Press.

PemerintahRepublik Indonesia. (2009). Undang-Undang Republik Indonesia Nomor 29 Tahun 2009 tentangPerubahanAtas Undang-Undang Nomor 15 Tahun 1997 tentangKetransmigrasian. Jakarta: Sekretariat Negara.

Romdiati, H.,\&Noveria, M. (2002). Mobilitaspenduduk dan implikasisosialekonomi di Kabupaten Bolaang Mongondow Provinsi Sulawesi Utara. Jakarta: LIPI.

Saksono, H. (2011). Kajian peranstrategistransmigrasidalamimplementasi MP3EI. JurnalKetransmigrasian, 28(2), 67-77.

Saleh, H.H. (2005). Transmigrasi: antarakebutuhanmasyarakat dan kepentinganpemerintah. Jakarta: PustakaSinarHarapan.

Slamet, M. (2003). Meningkatkanpartisipasimasyarakatdalampembangunanperdesaan. Di dalam: Sudradjat, A, \&Yustina, I (Eds). Membentuk Pola PerilakuManusia Pembangunan (pp 7-13).Bogor: IPB Press

Soekanto, S. (1996). Sosiologisuatupengantar. Jakarta: Raja GrafindoPersada.

Tulak, P.P., Dharmawan, A.Y., \&Juanda, B. (2009). Strukturnafkahrumahtanggapetanitransmigran. JurnalTransdisiplinSosiologi, Komunikasi, dan EkologiManusia. 3(2), 203-220. 